\title{
Law, Society, Identity and the Making of the Jim Crow South: Travel and Segregation on Tennessee Railroads, 1875-1905
}

\section{Citation}

Kenneth W. Mack, Law, Society, Identity and the Making of the Jim Crow South: Travel and Segregation on Tennessee Railroads, 1875-1905, 24 L. \& Soc. Inquiry 377 (1999).

\section{Published Version}

http://dx.doi.org/10.1111/j.1747-4469.1999.tb00134.x

\section{Permanent link}

http://nrs.harvard.edu/urn-3:HUL.InstRepos:2790089

\section{Terms of Use}

This article was downloaded from Harvard University's DASH repository, and is made available under the terms and conditions applicable to Other Posted Material, as set forth at http:// nrs.harvard.edu/urn-3:HUL.InstRepos:dash.current.terms-of-use\#LAA

\section{Share Your Story}

The Harvard community has made this article openly available.

Please share how this access benefits you. Submit a story.

Accessibility 


\title{
Law, Society, Identity and the Making of the Jim Crow South: Travel and Segregation on Tennessee Railroads, 1875-1905
}

\author{
Kenneth W. Mack* \\ 226D Harrison Lane \\ Princeton, NJ 08540 \\ Telephone: (609) 279-0319 \\ Fax: (609) 279-0319 \\ e-mail: kenmack@princeton.edu \\ Approximate Character Count: 71,700 \\ Copyright (C) 1998 by Kenneth W. Mack.
}

* Kenneth W. Mack is a Ph.D. candidate in History at Princeton University. The author would like to thank Hendrik Hartog, Nell Irvin Painter, Glenda Elizabeth Gilmore, Sarah Barringer Gordon, Judith Jackson Fossett, Frank Ravitch, Crystal N. Feimster, Simone E. Ross and the anonymous reviewers of Law and Social Inquiry who all read prior drafts of this article and contributed to its improvement. Prior drafts were also presented at the 1996 Annual Meeting of the Law and Society Association in Glasgow, Scotland, the 1996 Annual Meeting of the American Studies Association in Kansas City, Missouri, and the September 1995 Princeton University Graduate Women's Studies Colloquium. 


\title{
Law, Society, Identity and the Making of the Jim Crow South: Travel and Segregation on Tennessee Railroads, 1875-1905
}

\author{
Kenneth W. Mack
}

$\underline{\text { Abstract }}$

This article reexamines the well-known debate over the origins and timing of the advent of de jure segregation in the American South that began in 1955 with the publication of C. Vann Woodward's The Strange Career of Jim Crow. Arguing that the terms of the debate over Woodward's thesis implicate familiar but outmoded ways of looking at sociolegal change and Southern society, the article proposes a reorientation of this debate using theoretical perspectives taken from recent work by legal historians, critical race theorists, and historians of race, class and gender. This article examines the advent of railroad segregation in Tennessee (the state that enacted the nation's first railroad segregation statute) in order to sketch out these themes, arguing that de jure segregation was brought about by a dialectic between legal, social and identity-based phenomena. This dialectic did not die out with the coming of de jure segregation, but rather continued into the modern era. 
On September 15, 1883, a young Ida B. Wells boarded a train from Memphis, Tennessee to the nearby town of Woodstock, where she taught school, and entered an ongoing debate over law, society and identity in late nineteenth-century Tennessee. Wells, the future civil rights crusader, was concerned about railroad companies' recent attempts to segregate passengers by race, and about drinking and smoking on the train. Taking her seat in the nonsmoking rear coach which, according to the railroad, was reserved for "white ladies and gentlemen," she refused the conductor's request that she move to another car. The conductor, aided by two other men, physically ejected her from the car, in the process tearing her dress but suffering a serious bite wound inflicted by Wells in return. Ida Wells later sued the railroad for this incident and a subsequent ejection, ultimately losing in the state supreme court and incurring several hundred dollars in court costs in the process. ${ }^{1}$ (Chesapeake, O. \& Sw. R.R. v. Wells 1885a, 1885b \& 1887; Duster 1970) Disappointed with the outcome of her suit, Wells confided to her diary that "I have firmly believed all along that the law was on our side and would, when we appealed to it, give us justice." (DeCosta-Willis 1995, 141) Wells' views of the importance of the law in settling questions of identity, place and race mirrored those of her fellow Tennesseans. By the

1 The sometimes-cited date of Wells' ride, May 4, 1884, is incorrect. Wells was ejected twice and brought two lawsuits, the second of which was for the May 1884 ejection. The source of this confusion is Wells' autobiography, written over forty years later, where she fails to make clear that she was ejected twice and brought two lawsuits. In addition, the state supreme court opinion in her case, for reasons that are unclear, only references the lawsuit growing out of the 1884 ejection. (Duster 1970; Chesapeake, O. \&Sw.R.R.v. Wells 1887) This article will only reference the first lawsuit, except where it is necessary to distinguish between Wells' suits. 
1870 s and 1880s, the law of common carriers had emerged as a crucial battleground in the working out of the social, political and economic order in the New South.

\section{Law, Society and the Career of The Strange Career of Jim Crow}

The law of common carriers is an important element in C. Vann Woodward's much-debated thesis, set out in The Strange Career of Jim Crow, concerning the establishment of racial segregation in late nineteenth-century Southern life. Woodward argued that the period was characterized by experimentation in Southern race relations, and that rigid and widespread racial segregation did not emerge until the turn of the century, when Southern states enacted a wave of segregation laws. (Woodward 1974) ${ }^{2}$ Woodward's critics contended that many aspects of racial segregation, even if not always enshrined in positive law, were put in place shortly after the Civil War if not before. ${ }^{3}$ Legal scholars weighed in on the side of the critics, arguing that judicial decisions upholding separate-but-equal had endorsed Jim Crow practices long before Southern states began enacting segregation statutes in the late 1880s and 1890s. (Riegel 1984; Lofgren 1987, 116-47) According to Woodward's critics, the late nineteenth-century push for pervasive de jure segregation was merely a novel manifestation of longstanding trends in Southern life.

2 For an excellent summary of Woodward's argument, see Cell 1982, 82-94.

3 Examples of major works in the debate are: Williamson 1984; Cell 1982; Rabinowitz 1978;

Rabinowitz 1976; Blassingame 1973; Williamson 1965; Wade 1964; Wynes 1961; Litwack 1961. The fullest overview of the debate, and of the various editions of Strange Career that incorporated some of the criticism, can be found in Rabinowitz 1988. Other useful overviews are: Woodward 1986, 81-99; Woodward 1971b, 234-60; Williamson 1968. 
If Woodward, steeped in the lessons of progressive historiography, viewed the story of the late nineteenth century South to be one of conflict between men of different classes, many of his critics saw racial division rather than class conflict as the eternal verity of Southern society. ${ }^{4}$ Recent scholarship has sought to reorient the contours of the Woodward debate, interrogating the concepts of race and class themselves. Much of this newer scholarship has used the categories gender and sexuality to break race and class down into their component parts, and in turn used race and class to break down these categories. ${ }^{5}$ Newer scholars have added gender and sexuality to insights taken from both Woodward and his critics, for example arguing that the most-cited rationale for racial segregation -- the need to reduce contact between black men and white women -- while drawing on racial anxieties with longstanding roots in Southern culture, was the product of race, gender and class conflicts growing out of political and economic changes taking place in the New South. White supremacy, according to this scholarship, was a means of containing and disciplining these conflicts, and hiding them behind a facade of white racial unity. (Edwards 1997; Hodes 1997; Gilmore 1996; Bardaglio 1995; Somerville 1995; Greenwood 1994; MacLean 1994; Painter 1988; Hall 1983; Hall 1979)

4 Woodward traced some of the themes that would emerge in Strange Career in his earlier work, Origins of the New South. (Woodward 1971a, 209-12, 321-95) A brief, early argument for the emergence of a new urban black middle class as an impetus for the adoption of de jure segregation is contained in Rabinowitz 1978, 334-36.

5 For an insightful analysis of the interactions of race, class, gender and sexuality in American culture, see Higginbotham 1992. 
Similarly, recent scholarship has examined black responses to the hardening of white racial attitudes in the Jim Crow South, and in the country as a whole. Examining issues such as class and gender divisions in black communities, the emergence of uplift ideology, and alternate avenues for black politics, historians have analyzed how African-Americans constructed new identities for themselves in a society that seemed bent on denying their citizenship. This scholarship serves as a curative for the Woodward thesis' disproportionate focus on white attitudes towards blacks rather than black responses to segregation. (Edwards 1997; Hunter 1997; Dale 1997; Bates 1997; Gaines 1997; Gaines 1996; Gilmore 1996; Brown 1994; Greenwood 1994; Kelley 1994; Higginbotham 1993)

Recent legal scholarship has also addressed an issue that occupied center stage in the Woodward debate -- the role of law in American society. Writing in the shadow of Brown v. Board of Education, Woodward argued that newly-enacted segregation laws contributed significantly to a lessening of interracial social contact in the turn-of-the-century South (thus implying that Brown and subsequent legal initiatives could change things for the better in the modern South). Woodward's critics, writing at a time of greater pessimism about the efficacy of law in changing racial attitudes, argued that the coming of de jure segregation merely ratified what had been put into practice long before. (Woodward 1974, 102-09; Woodward 1986, 96; Cell 1982, 91, 94; Rabinowitz 1988, 849; Rabinowitz 1976, 349; Williamson 1984, 253) This disagreement over the efficacy of law is a form of a familiar law-and-society debate that current legal scholarship has sought to reorient.

Instead of viewing law as either a cause or a product of social change, recent work in legal history and critical race theory has sketched the complex and often contradictory ways that laws and legal doctrine interact with race, gender and class identity. Legal historians have 
analyzed the ways that both litigants and nonlitigants used laws and legal categories to press for social change, but at the same time were often imprisoned by the identities that those categories constructed for them. (Hartog 1997; Dale 1997; Gordon 1996; Klarman 1994; Tomlins 1993; Forbath 1991; Clark 1990; Hartog 1987; Forbath, Hartog and Minow 1985) ${ }^{6}$ Critical race theorists have argued that facially neutral laws and legal doctrines often perpetuate race and gender privilege, and that racial identity itself can be a creation of law. ${ }^{7}$

The above scholarship suggests that a central problem that occupied Woodward and his critics -- the emergence of de jure segregation in public conveyances -- should be revisited, albeit from differing perspectives than those that drove the Woodward debate. Rather than focusing on the primacy of race or class, or the temporal ordering of legal and social change, the analysis below describes how new sociolegal arrangements in an important New South community emerged through the interplay of law, social change and identity formation. De jure and de facto race segregation emerged in fits and starts as various groups of Tennesseans made strategic use of legal doctrine and social structures to argue for their asserted place in the polity. However, Tennesseans could not keep their arguments within the bounds that they set -- an argument about race could quickly become one about class or gender, or vice versa. They as often found themselves constrained by categories of law and identity as liberated by them.

\footnotetext{
6 An important precursor to this scholarship is Thompson 1975, especially pages 258-69.

7 Prominent examples include: López 1996; Davis 1994; Harris 1993; Williams 1991. On critical race theory generally, see Wing 1997; Crenshaw et al. 1995; Delgado 1995.
} 
Sociolegal change in the New South occurred through a dialectical process, as it does in our own. ${ }^{8}$

8 Two excellent 1995 articles addressed the intersection of race, class and gender in the emergence of segregated railroad transit in the New South (Welke 1995, Minter 1995), although both were published too early to take full advantage of the transformation in the Woodward debate wrought by the last few years worth of scholarship. Welke, for example, sides with Woodward's critics, asserting that postbellum white Southerners were committed to "preserving the pre-Civil War social and racial status quo" in railroad travel, and that this social need drove Southern railroad practices and laws inexorably in the direction of strict racial segregation after the war. (Welke 1995, 277, 295, 313, 314) Both articles, nonetheless, constitute groundbreaking attempts to point the way towards a reinterpretation of the emergence of de jure segregation. This article attempts to further the process of such a reinterpretation, taking advantage of the wealth of studies of the postbellum South published between 1994 and 1998. 


\section{$\underline{\text { Railroad Travel and Identity in Late Nineteenth-Century Tennessee }}$}

In the 1870 s and 1880 s, railroad travel complicated Southern notions of identity. In the antebellum period, when white men had confidently assumed that they represented the interest of their dependents -- slaves, women and children -- in public life, travelers sometimes reported seeing a surprising degree of interracial intimacy on the trains. (White 1978, 14-15, 46263) Such easy confidence in social hierarchies could not be presumed in the postbellum period, when whites were forced to share the rails with newly-emancipated black citizens. While in certain areas of race relations -- marriage and schooling, for instance -- white Southerners responded quickly to black emancipation by introducing de facto and de jure separation of the races, strict racial segregation of railroad cars was not imposed until the 1890s. ${ }^{9}$ Railroad cars were a relatively unfamiliar mode of travel for many Southerners until the 1870 s and 1880 s, when railroad companies began a massive program of expansion and consolidation in the region. Railroads, as both metaphor and reality, were markers of the economic changes overtaking the New South. A railroad station could quickly transform a backwater town into a thriving center of commerce, complete with new classes of citizens, both black and white, men and women, riding the rails on their own behalf. (Stover 1955, 25, 61, 190-93; Ayers 1992, 9-13, 136-46; Thomas 1995, 1-17) Ida B. Wells' 1883 trip, for instance, was a product of her membership in Tennessee's newly-formed black middle class -- she needed to ride to Woodstock, where she had obtained a teaching job. In the postbellum era, Southerners might encounter strangers aboard the

9 Postbellum Southern intermarriage and school segregation laws drew upon substantial legal precedents from the antebellum period and earlier. (Johnson 1979, 8-14, 51-52) 
trains without fixed rules of deference and courtesy. It would take several decades to fashion new rules, and refashion old ones, to determine which passengers would ride where on the trains.

Tennesseans, like their fellow New Southerners, struggled to map the race, gender and class contours of the new social space that railroad cars presented. Tennessee stood at an important crossroads in the Southern rail transit network, with several of the region's largest railroad networks passing through its territory. Like those of other Southern states in the period, Tennessee's cities burgeoned with African-Americans who moved to town in the postwar period and encountered whites in public spaces like restaurants, theaters, and railroad cars. The state legislature enacted the nation's first, although ambiguous, railroad segregation law in 1881, inaugurating a new issue -- de jure railroad segregation -- that Southerners would grapple with through the end of the century. ${ }^{10}$ (Stover 1955, 61, 190-202; Cartwright 1976; 1881 Tenn. Acts, Ch. $155, \S 1)$

Like other nineteenth-century Americans, Tennesseans first responded to the social spaces that railroad travel created by reorganizing them into the familiar world of patriarchy, where middle class white women, when they entered the public sphere, remained under the protection of white men. In 1870 s and 1880s, Tennessee trains often contained two passenger cars -- a smoking or second class car, and a ladies' or first class car. Railroads generally reserved ladies' cars for ladies and for gentlemen accompanying them, although in actual practice the middle and upper classes, generally whites, rode in the ladies' cars. White men frequently traveled

10 Three Southern states had enacted laws dealing with aspects of railroad segregation in 186566, but these were soon superseded by state civil rights laws during Congressional Reconstruction. (Johnson 1979, 14-16, 54; Woodward 1974, 23-24; Lofgren 1987, 18) 
alone in them, giving up their seats to ladies when the cars became overcrowded. Only the virtuous merited such protection, however, and lower class white women, often seen to be lacking in virtue, sometimes rode in the smoking cars. (Chesapeake, O. \& Sw. R.R. v. Wells 1885a \& 1885b; Memphis \& C. R.R. v. Benson 1884 \& 1887; Murphy v. Western \& A. R.R. 1882 \& 1885; Brown v. Memphis \& C. R.R. 1880b, 502; Brown v. Memphis \& C. R.R. 1881, 59)

The smoker was usually placed in front of the ladies' car, where it would be closer to soot and noise from the engine. On some routes, the smoking car was divided into a "combination car," using a partition. The combination car might have one side for smokers and one for baggage, or one side for smokers and one for nonsmoking second class passengers, or later, as racial attitudes hardened, one side for smokers and one for blacks. Even where there was a designated black compartment on the train, railroad officials made few distinctions between the black section and the smoking compartment, and focused instead on keeping blacks from riding first class. ${ }^{11}$ (Councill v. Western \& A. R.R. 1887b; Terrell 1940, 15-16, 296-98; White 1978, $462-63)$

11 Although the preceding several paragraphs describe the specific form that patriarchy took in Southern railroad transit, patriarchy might more generally be described as an always-contested system of hegemonic sociolegal practices that position women and children, in private and public life, only the context of their dependent relationships with men. (Yngvesson 1997, 37 n. 3) The ideology of the antebellum South analogized the position of African-American slaves to that of women and children in the household. The long struggle over railroad segregation was, in part, a consequence of the challenges posed to this antebellum world by emancipation, black citizenship and the economic changes occurring in the New South. More general discussions of the 
It is important to note that the railroads' initial response to the challenges of postbellum train travel were generally based on class and gender assumptions rather than those of race. Contemporary observers generally agree that strict racial segregation, both by custom and by law, did not occur until later in the postbellum era. (Duster 1970, 18; Terrell 1940, 298) Many blacks, particularly the less respectable, had difficulty gaining access to ladies' and first class cars in this period, but railroads paid little attention to the racial composition of the passengers traveling second class. Railroad companies apparently assumed that few, if any, blacks would attain the necessary level of respectability to ride first class. The typical black passenger could mix freely with white second class passengers without objection.

The law required that ladies' and smoking cars offer the same quality of physical accommodations when passengers were charged a uniform fare. Courts generally ruled that railroads could separate their passengers by gender or race without violating either their duties as common carriers under state common law or the federal Civil Rights Act of 1875, so long as the separate cars were of equal quality. If two passengers paid the same fare, then railroads had to furnish them with substantially equal quality of passage. (Logwood v. Memphis \& C. R.R., 1885; Chesapeake, O. \& Sw. R.R. v. Wells 1885a, 64-66; Brown v. Memphis \& C. R.R. 1880b; Robinson v. Memphis \& C. R.R. 1879, 17) Black passengers in smoking cars often asserted that smoking, drinking and swearing in those cars gave rise to tangible discomforts not present in first class, although in court these passengers had difficulty proving that the second class cars were

challenges posed to the Southern legal system by the breakdown of the antebellum household structure can be found in Edwards 1997; Bardaglio 1995. For a similar discussion, focusing on the color line and miscegenation, see Hodes 1997. 
actually physically inferior. ${ }^{12}$ (Chesapeake, O. \& Sw. R.R. v. Wells 1885b, 11; Robinson v. Memphis \& C. R.R. 1879, 8; Logwood v. Memphis \& C. R.R. 1885)

While many blacks complained of inferior physical accommodations, what was mainly at stake when blacks claimed access to ladies' cars was class and gender status. By the late 1870s and 1880s, railroad companies' assumption that black riders would be content with second class passage was subject to question. Urban areas like Memphis contained a nascent black middle class composed of teachers, ministers, seamstresses, shop owners, boarding house operators and a few doctors and lawyers. (DeCosta-Willis 1991 \& 1995) Middle class white men and respectable white women rode in ladies' cars, and these blacks sought the imprimatur of middle class identity that riding in such cars bestowed. Black Tennesseans' attempts to claim the patriarchal privileges, and protections, of the ladies' car would call into question a system whose official categories were those of gender and class. ${ }^{13}$

Railroad Segregation and the Law in the 1870s and 1880s

12 One case where a black plaintiff proved that accommodations were unequal was Councill $v$. Western \& Atlantic R.R. 1887b.

13 As Patricia Schechter has noted, access to nonsegregated trains was important to middle class blacks both as a reflection of their material wealth and as a symbol of their status. (Schechter 1993, 33) Accordingly, the term "middle class" is used here to denote more than material wealth or income. 
In 1870 s and 1880 s, the battle over black access to first class Tennessee railroad cars began with the enactment of the federal Civil Rights Act of $1875 .^{14}$ The Act, extending federal protection of civil rights to public inns, transportation, theaters and "other places of public amusement," provoked a quick response in Tennessee. Within a month of the Act's passage, the state legislature enacted its own law abolishing the state common law right of equal access to public accommodations and transportation. While the state legislature had no power to take away the rights granted by the federal act, it could remove any parallel rights that its black citizens might enjoy under state law. (Civil Rights Act of 1875; 1875 Tenn. Acts, Ch 130; Cartwright $1976,102)$

In 1881, the four black Republicans serving in the state legislature began a protracted campaign to repeal the Tennessee statute. Their initial repeal effort, which even gained the support of a few Democrats, was defeated 31-29 in the state assembly. Subsequently, a black legislator began pushing a bill that would have banned racial discrimination on Tennessee railroads. Instead, the legislature adopted a substitute measure, calling it an act to "prevent discrimination" by railroads. The 1881 statute disapproved of the practice of charging blacks first class fares and relegating them to second class smoking cars. The act required that railroads instead provide "separate cars, or portions of cars" for first class black passengers. The statute is sometimes referred to as the South's first state law mandating railroad segregation, although the act was vaguely worded and seems to have required only that first class black passengers be given

${ }^{14}$ In 1868, Tennessee's Radical Republicans had enacted a state statute prohibiting racial segregation in railroad travel, but the statute was soon repealed with the establishment of conservative rule in the state in 1869. (Tennessee Act of March 12, 1868; Cartwright 1976, 14) 
access to first class, presumably segregated, passage. (1881 Tenn. Acts, Ch. 155, § 1; Folmsbee 1949; Cartwright 1976, 102-08; Lofgren 1987, 21) In 1882, the legislature made the situation even more indeterminate by amending the statute, requiring that railroads allow all first class passengers "to enter and occupy first-class passenger cars." The new statute did not, on its face, even require segregation. (1882 Tenn. Acts, 3d Extraordinary Sess., Ch. 6)

The motivations behind the enactment of the 1881/82 statutes appear to have been a combination of racial segregationist purposes and paternalistic concern for the treatment accorded middle class black passengers. In the mid-1880s, white paternalistic sentiments were such that prominent Democrats would champion enforcement of the 1881 statute in a bid to attract black voters to the party, albeit with little success. Several of the black state legislators' efforts to repeal the 1875 law received substantial support from their white colleagues, and when the 1882 measure was introduced a black legislator was responsible for raising the penalty for violation of the statutory regime from $\$ 100$ to $\$ 300$. Although black legislators continued to introduce measures to repeal the 1875 and $1881 / 82$ laws, he was apparently swayed by both the ambiguity of the statutory regime and the need to give some protection to first class black passengers. ${ }^{15}$ (Cartwright 1976, 43-47, 103-06, 168-71)

Such ambiguous sentiments concerning railroad segregation were not confined to Tennessee. In 1887, Florida followed Tennessee's lead and enacted a railroad segregation law

15 In 1887, the legislative compromise embodied in the 1881/82 statues would be eviscerated by the state supreme court in Ida B. Wells' case. There Chief Justice Peter Turney, ignoring both the statute's language and the evidence adduced at trial, held that the railroad's smoking car was a first class car for blacks as required by the statutes. (Chesapeake, O. \& Sw. R.R. v. Wells 1887) 
that only applied to first class passengers, requiring that railroads provide "respectable" blacks with segregated first class passage, and prevent whites from riding with, "insult[ing]" or “annoy[ing]" those respectable blacks. Texas' 1889 foray into the field of railroad segregation amounted to little more than a codification of the common law, permitting, but not requiring, racial segregation in railroad travel. The statute did, however, prescribe small criminal fines for passengers who rode in the other race's coach. ${ }^{16}$ (1887 Florida Acts, Ch. 3743; 1889 Texas Gen. Laws, Ch. 108)

In Tennessee, most evidence indicates that new state laws, like the Civil Rights Act of 1875 , had little direct effect on railroad travel. With respect to the civil rights act, many black plaintiffs avoided it and sued under the common law instead, probably because the civil rights act limited damages to $\$ 500$, while blacks could and did sue for thousands of dollars in damages under the common law. ${ }^{17}$ (Civil Rights Act of 1875, § 2; Brown v. Memphis \& C. R.R. 1880b;

16 The purported quotation of this statute in Johnson, 1979, is incorrect. (Johnson 1979, 189) Although Johnson is an essential reference guide on nineteenth-century legislation concerning African-Americans, the book often paraphrases the federal and state laws that it purports to reprint. In this case, the paraphrase misleadingly implies that the Texas statute required racial segregation when it merely permitted it.

17 The civil rights act allowed plaintiffs to sue under its provisions or under state common/statutory law, but not both. (Civil Rights Act of $1875, \S 2$ ) One black plaintiff even cited the language of other federal civil rights laws, as well as the common law, while neglecting to sue under the provisions of the Civil Rights Act of 1875, which directly applied to public accommodations. (Murphy v. Western \& A. R.R. 1882) The 1875 civil rights act was only 
Murphy v. Western \& A. R.R. 1882; Logwood v. Memphis \& C. R.R. 1883 \& 1885) Moreover, courts interpreted the civil rights act to require no more than what the common law allowed -separate-but-equal accommodations. ${ }^{18}$ (Riegel 1984; Lofgren 1987, 116-47) Tennessee's state statutes were similarly ineffective with regard to racial segregation. Until the early 1880s, Tennessee railroads' litigating position was that they drew no racial distinctions in their cars, despite the 1875 Tennessee statute's invitation that they do so. In fact, litigants in ladies' car cases largely ignored the 1875 state law's apparent abrogation of the common law right to equal access to railroad cars. ${ }^{19}$ (Chesapeake, O. \& Sw. R.R. v. Wells 1885a \& 1885b; Robinson v. Memphis \& C. R.R. 1879, 9; Brown v. Memphis \& C. R.R., 1880a) The 1881/82 laws did not cause railroads to add a second car to accommodate first class blacks. Indeed, by the mid-1880s, railroad conductors grew more intent on confining first class black passengers to smoking cars than they had been before passage of the 1881/82 laws. (Duster 1970, 18; Murphy v. Western \& A. R.R. 1885; Logwood v. Memphis \& C. R.R. 1885)

available to plaintiffs until October 1883, when the Supreme Court struck down most of its provisions in the Civil Rights Cases.

18 On the civil rights act's generally ineffective enforcement nationwide, see Franklin 1974.

19 The litigants may have concluded that the 1881/82 laws had restored the common law regime, at least with respect to first class passengers. The trial judge in Ida B. Wells' case concluded that the 1881/82 laws had merely enacted common law rules into positive law. (Chesapeake, O. \& Sw. R.R. v. Wells 1885a) In one case, brought before the 1881/82 laws were enacted, a federal judge charged a jury that the 1875 state law, as applied to interstate passengers, was an unconstitutional attempt to regulate interstate commerce. (Brown v. Memphis \& C. R.R. 1880b) 
These, however, are not the only measures of the laws' effectiveness. Despite its lack of direct effect on railroad segregation, the Civil Rights Act of 1875 was the focus of much attention in Tennessee. White Tennesseans' fears that the Act would dramatically change social relations prompted the state legislature's 1875 modification of the common law, which was the first step in a process that ultimately would lead to the institution of de jure railroad segregation in the 1890s. White reaction would also find justification in a federal judge's ruling handed down less than a month after the civil rights act's passage, where circuit judge Emmons took the U.S. Congress to task for enacting this "almost grotesque exercise of national authority." Judge Emmons charged a west Tennessee grand jury that the Civil Rights Act of 1875 was unconstitutional, exceeding Congress' power under the Thirteenth and Fourteenth Amendments to the United States Constitution. ${ }^{20}$ (Charge to Grand Jury -- Civil Rights Act 1875)

Tennessee's African-Americans were equally emphatic in their reactions to the law of segregation. The postbellum civil rights acts and constitutional amendments figured prominently in black responses to segregation, despite the unwillingness of many blacks to sue under the 1875 civil rights act's provisions. One black witness from Chattanooga, testifying on behalf of a plaintiff challenging railroad segregation, stated that his reason for testifying was that "the negro race is a part and parcel of the community, and ought to be protected by the laws of this country and the constitution." Mary Church Terrell later wrote in her autobiography that

20 Judge Emmons' grand jury charge was probably not the reason that black plaintiffs declined to sue under the civil rights act. Four years after Judge Emmons' ruling, a case was litigated in the same court under the civil rights act without either side raising the issue of the act's constitutionality. (Robinson v. Memphis \& C. R.R. 1879; Civil Rights Cases 1883, 4-9) 
getting first class accommodations in 1880s Tennessee was a matter of blacks insisting "upon their rights, without violating the State law." Segregationist laws could serve a similar catalytic function. Black Nashvilleans used the 1881 Tennessee law, as well as the Civil Rights Act of 1875 , as an inducement to organize a three-day civil disobedience action against railroad segregation. ${ }^{21}$ (Councill v. Western \& A. R.R. 1887a, Grizzard Depo.; Terrell 1940, 298; Cartwright 1976, 184) Even common law judicial decisions, which justified separate-but-equal, could be a useful tool in challenging segregation. Many black plaintiffs in smoking car litigation brought suit under the common law, arguing that smoking cars were in fact unequal, that accommodations offered first class passengers were superior, and that blacks therefore should be allowed to ride first class.

While neither federal nor state law made a substantial difference in social practices on Tennessee railroads in the 1870 s and 1880 s, this was not obvious to Tennesseans at the time. Black and white assertiveness on the issue often manifested itself in dialogue with changes in laws and legal doctrine. Tennesseans viewed the law of railroad travel as an important element in their struggle to define the contours of race, identity and place in their changing society. Their strategic uses of law, and their often contradictory social practices, raised not only race relations issues, but important issues of class and gender politics as well.

Black Women, "Character," and Access to Ladies' Cars

Among Tennessee's African-American population, middle class black women could make the most compelling claims for access to ladies' cars, but conductors sometimes

21 On black and white reactions to the civil rights act nationwide, see Franklin 1974, 226-28. 
excluded them because of "bad character." In the nineteenth-century South, and in Tennessee in particular, bad character was partly a euphemism for a woman's race and class status. The Southern legal system often presumed black and poor white women to have bad character when character was at issue, and courts ruled that railroads could validly exclude passengers from ladies' cars based on their character. ${ }^{22}$

Conductors were the main gatekeepers regulating access to ladies' cars, and thus could help determine the character, and by extension the race and class status, of the women riding the trains. The law, however, did not allow conductors to make entirely subjective judgments about character, or to use character merely as a stand-in for race. Conductors had to have objective reasons for thinking that a woman excluded from a ladies' car would act in a way that was offensive to other passengers. (Murphy v. Western \& A. R.R. 1882 \& 1885; Brown v. Memphis \& C. R.R. 1881, 57-62; Brown v. Memphis \& C. R.R. 1880b, 502; Robinson v. Memphis \& C. R.R. 1879, 13) Black women took advantage of these limits on conductors' powers to gain access to ladies' cars, although they still had to negotiate nineteenth-century images of black womanhood that seemingly justified their exclusion.

22 On character, similar euphemisms, and access to ladies' cars in Tennessee, see Murphy v. Western \& A. R.R. 1885, 640; Murphy v. Western \& A. R.R. 1882, Jury Charge, 9-11; Logwood v. Memphis \& C. R.R. 1885, 319; Brown v. Memphis \& C. R.R. 1881, 57-62; Brown v. Memphis \& C. R.R. 1880b, 502; Robinson v. Memphis \& C. R.R. 1879, 13. Similar observations concerning nineteenth-century Southern society can be found in Edwards 1997, 200-05; Gilmore 1996, 72; Hodes 1997, 65-66, 161-65; Bardaglio 1995, 74-75; Somerville 1995, 481-518. 
Sallie Robinson, for instance, had remarkable difficulty getting into a ladies' car when she boarded the Memphis and Charleston Railroad at Grand Junction in 1879. Sometime after midnight, Sallie, "a young, good-looking mulatto woman about 28 years old," boarded with her nephew Joseph Robinson, "a young man of light complexion, light hair, and light blue eyes." The conductor barred their entry to the ladies' car, grabbing Sallie so roughly that her arm was bruised for a week. Later, when Joseph explained that Sallie was his aunt, the conductor realized that they were both black and let them into the ladies' car. Initially believing that they were an interracial couple, the conductor thought that they were traveling together for "illicit purposes." In his experience, an attractive black woman traveling with a young white man was "an improper character." (Robinson v. Memphis \& C. R.R. 1879, 7-9)

Jane Brown encountered similar difficulties traveling on the Memphis and Charleston from Corinth, just across the Mississippi border, to Memphis. Alleging that Brown was "a notorious courtesan, addicted to lascivious and profane conversation and immodest deportment in public places, and well known to the defendant's conductor as such," the railroad claimed that she had violated its regulation setting aside the ladies' car for persons of "good character." Brown had tangled with this same conductor twice before, and she resisted her removal from the ladies' car. The conductor ejected her with violence, causing a dislocated thumb and injuries from "severe choking." (Brown v. Memphis \& C. R.R. 1880a, 38; Brown v. Memphis C. R.R. $1881,58,67)$

One thing seems fairly certain: if any women were to be excluded from ladies' cars, it would be the Jezebels. The image of the Jezebel, the sexually promiscuous black woman, helped solidify the class status of the white women riding in ladies' cars, and possibly that of the 
white men as well. ${ }^{23}$ The idea of the Jezebel played on the image of sexual immorality that was often associated with black and poor white women in the New South. No ladylike treatment was necessary for presumed Jezebels like Robinson and Brown. If they resisted ejectment, conductors sometimes used abundant force. The delicate female constitutions that justified the creation of ladies' cars would not be presumed for such women..

While railroad conductors excluded Jezebels from ladies' cars, at least some black women did gain admittance. The easiest class of black women to admit were those that the legislature chose not to segregate when it finally imposed strict railroad segregation in 1891 -black nurses. Nurses were the only class of persons whom the 1891 statute exempted from the segregation requirement. ${ }^{24}$ (1891 Tenn. Acts, Ch. 52) The nurse exception relied on an image of nineteenth-century black womanhood that was the opposite in many ways of the Jezebel -- the mammy. As asexual, subservient women, presumed mammies could gain admittance to ladies' cars without disturbing either prevailing notions of ladylike chastity or the dominant class relations. $^{25}$

Black nurses were welcomed into Tennessee ladies' cars throughout the 1880s. In Ida B. Wells' case for instance, the same conductor who ejected Wells testified that he would

23 On the idea of the Jezebel, see Collins 1991, 77-78; Painter 1988, 58; White 1985, 27-46; hooks 1981, 33.

24 Although worded in race-neutral terms, the provision seems to have been written solely for the benefit of whites accompanied by black nurses. Many Southern railroad segregation laws contained nurse exceptions. (Lofgren 1987, 22, 214 n. 36)

25 On the idea of the mammy, see Collins 1991, 71-73; White 1985, 46-61; hooks 1981, 84-85. 
never object to black nurses riding first class. Virginius Kimbrough, a white passenger traveling on the train, testified that his initial conclusion upon seeing Wells in the first class coach was that she was a nurse. Kimbrough stated that no passenger would have objected to her presence had she conducted herself "in a proper manner." (Chesapeake, O. \& Sw. R.R. v. Wells 1885a, 34, 49, 50)

Wells' encounter with Kimbrough, like Robinson's troubles on the Memphis and Charleston, reveals a degree of instability in the dominant images of black womanhood. Black women could escape from these images and refashion themselves as respectable ladies depending on how they acted, what they wore and who they accompanied. Middle class black women played on the intersection of class and gender assumptions that justified ladies' cars -assumptions that admitted respectable women, their male escorts and their servants, and worked against those with markers of lower class status. Making themselves respectable, however, was not a complete solution, because respectability cut in two different directions. Proper character and ladylike demeanor was their key to admission to the ladies' car, since few of them would be content to ride as servants. At the same time, the respectability that was a prerequisite for such access could be seen as a threat to the status of whites.

Anna Logwood's trouble getting her usual sear in the ladies' car of an Alabama-toMemphis line in 1882 seems perplexing, except for the testimony of a white passenger, a salesman, who noticed what he took to be her conspicuous arrival at the station accompanied by "her colored friends." According to him, "[s]he was putting on considerable style and from all I saw I felt certain that it was a fixed up arrangement to have some fuss or trouble with a R.R. Co.” Logwood was ill and arrived at the depot accompanied by friends. A white doctor who had treated her was also present. Such an entourage certainly made her respectable, but perhaps too 
respectable in the eyes of a white salesman whose own class status may have been uncertain, and those of other white passengers on the train. Similarly, in Ida B. Wells' case, Virginius Kimbrough stated that he had no problem with her presence initially, believing her to be a nurse. Wells' sin, apparently, was that she got into a dispute with Kimbrough's wife and forced Mrs. Kimbrough to give up her seat. Angered by the incident, Kimbrough complained to the conductor, who himself remembered getting into a dispute with Wells a week earlier. Wells, apparently having taken her notions of respectability too far, was ejected. ${ }^{26}$ (Logwood $v$. Memphis \& C. R.R. 1883; Chesapeake, O. \& Sw. R.R. v. Wells 1885a, 29-30, 48-50)

Middle class black women, therefore, faced a paradox. To gain access to ladies' cars and claim the mantle of respectability, they often had to appear subservient and deny that very respectability. As federal judge David Key summed up the situation in an 1885 speech to the Tennessee Bar Association:

[s]o long as a colored passenger occupies a servile position, he may ride anywhere. Let a woman black as midnight be the nurse of a white child, or a man equally as dark be the servant of a white man [and] there is never the slightest objection to their having seats in the ladies car or any other. All the scents of Africa or from it are inoffensive; but let these same two persons by saving the wages earned in such service become the owners of

26 On Wells' use of anger and her continuing difficulties with conventional ideas of respectability, see Schechter 1998. 
property and undertake to travel upon their own business, and they will in many lines be turned out of the ladies car into the smoker as repulsive to those aboard the better car. ${ }^{27}$

(Key 1885) For the black middle class, respectability was an ambiguous asset.

Moreover, the form that this respectability took is important for understanding why access to ladies' cars was so important to middle class black women. The story of Mary Church (later Mary Church Terrell), one of Wells' Memphis acquaintances, is a useful example. By age five, she had already learned the relation between ladylike demeanor and access to first class railroad cars. Traveling in a first class car with her father, she was temporarily separated from him and was almost forced to ride second class by the white conductor. Upon returning home she assured her mother that her hands and face had been clean, her clothes neat and her comportment proper. Since she was "behaving like a little lady," she could not understand why the conductor wanted to put her in the second class car. After all, explained Church, "selfrespecting colored people" would never go into such coaches. An older Mary Church later learned what lurked in the second class cars when returning from college, nearly exiting the train in a strange town rather than remain alone in the car "at the mercy of the conductor or any man who entered." (Terrell 1940, 15-16, 297) Both the real threat of sexual assault and the aura of immorality associated with smoking cars made riding first class imperative.

27 A slightly different version of Key's speech may be found in: Proceedings 1885, 138-45. Black Tennesseans mounted similar critiques of the differing treatment received by respectable and subservient blacks aboard the trains and in public life. (Cartwright 1976, 186-87, 194) 
Many middle class black women of Church's generation and later adhered to forms of bourgeois respectability described in the work of Evelyn Brooks Higginbotham and others. Respectability of this sort demanded that black women give lie to dominant images of black female immorality with their unblemished conduct. Respectability emphasized that "[f]rom the public spaces of trains and streets to the private spaces of their individual homes, the behavior of blacks was perceived as ever visible to the white gaze." (Higginbotham 1993, 196) ${ }^{28}$ Such evident respectability provided a platform that enabled middle class black women to work for civil rights and the improvement of the circumstances of the black poor. Respectability, however, also reinscribed a morality tinged with racism and class consciousness, causing these respectable women to emphasize their distance from lower class blacks, whom they sometimes viewed as slothful and licentious. ${ }^{29}$ (Higginbotham 1993; McCluskey 1997; Knupfer 1995; White 1993)

By the 1880 s, the Southern black middle class in particular began turning to discourses of respectability for models of decorum. Calling themselves the "best people," the "better classes" and similar names, these black Southerners began to emphasize Christian morality, reform and respectable manhood and womanhood as qualifications for participation in Southern public life. The prohibition movement provided a vehicle through which some of these black women and men found political expression in the late nineteenth-century. In Tennessee and elsewhere, black chapters of the Women's Christian Temperance Union supplied an opportunity

28 For similar observations regarding black women riding Tennessee trains, see Schechter 1993, 33.

29 For a general discussion of the tension between middle class African-Americans' desire to both uplift and distance themselves from lower class blacks, see Gaines 1996. 
for black women to bring their emphasis on bourgeois respectability into the public sphere, where they expected to be met as equals by the white better classes. (Cartwright 1976; Edwards 1997; Gilmore 1996; Greenwood 1994)

Like her acquaintance Mary Church, Ida B. Wells was firmly ensconced in the respectable black world of 1880s Memphis, participating in its socials, recital readings and church activities. Wells published a series of articles around the time that her case was on appeal, in which she focused on the status and duties of respectable black women. In what was probably an autobiographical account entitled "A Story of 1900," Wells told the fictional story of a black schoolteacher in the 1880s. The teacher discovered that blacks' "moral and temporal status had not kept pace with [their] intellectual." After hearing about a black youth recently send to prison, she found her mission -- "to mould high moral characters" by "instilling elevated thoughts, race pride and ambition" in her students. Thus she discovered her life's work, which even extended to visiting her students' homes, "those where squalor and moral uncleannes [sic] walked hand in hand with poverty, as well as the better ones." Wells' prescription for moral uplift had special components for black women. In other contemporaneous articles she stressed black women's special duty to guard their virtue, in order to rebut charges of immorality attributed to the race. ${ }^{30}$ (Schechter 1998; DeCosta-Willis 1991 \& 1995; Iola 1886; Iola 1885; Iola 1887; Iola 1888)

${ }^{30}$ Wells, however, did struggle with notions of respectable womanhood that hemmed in a single, independent, ambitious woman such as herself. (DeCosta-Willis 1991, passim; Schechter 1993, 63) The turning point in Wells' struggle came when three black Memphians, including one of her closest friends, were lynched in 1892. Afterward, she launched her famous anti-lynching crusade, 
Such an emphasis on respectability partly explains Wells' determination to ride in a ladies' car. In her lawsuit, she testified that "[r]ougher people" rode second class, and that a "drunken white man" was riding in the smoker on the day of her trip. According to the conductor, she protested that she "would not ride with negroes." Other black women bringing suit also cited drinking and swearing as well as smoking in the second class cars as reasons for avoiding them. (Chesapeake, O. \& Sw. R.R. v. Wells 1885a, 20, 33; Logwood v. Memphis \& C. R.R. $1883 \&$ \& 1885) Such practices were the source of tangible discomfort, to be sure, but lurking behind this explanation is a vision of the lower class, particularly the black lower class, held by respectable black women such as Wells. While they demanded admission to ladies' cars for the sake of uplifting the lower class and countering negative images of blacks (by being respectable), they also needed admission to know themselves as different from the Jezebels and immoral men who rode second class. ${ }^{31}$

which included a powerful critique of Southern discourses of race, class and gender. (Duster 1970, 47; Schechter 1993, 83, 136-54)

31 Two groups who were noticeably absent from ladies' car cases were poor white women and lower class blacks. Lower class blacks lacked both obvious claim to seats in ladies' cars and the material wealth to incur the hundreds of dollars in court costs that Wells spent prosecuting her suit. Moreover, as Robin Kelley has argued, black lower class resistance to Southern racial oppression often took different forms from that of the black middle class. (Kelley 1994, 1-75) Although at least some poor white women rode second class, they seem to have obtained seats in ladies' cars when they wanted them. (Brown v. Memphis \& C. R.R. 1881, 59) The only group of white women who might be excluded from ladies' cars were white prostitutes, although the 


\section{Black Men, "Social Equality,” and Access to Ladies' Cars}

While adherence to the forms of middle class respectability helped black women attack Tennessee's race, class and gender hierarchies, black men faced a more difficult set of obstacles in their encounters with ladies' and first class cars. By some accounts, in the 1870s and early 1880s certain black men commanded enough respect to ride first class with regularity. (Terrell 1940, 15-16, 295-96; Murphy v. Western \& A. R.R. 1882, Murphy Test.) Railroad segregation became a central drama in black and white politics in the 1880 s, however, exposing the particular barriers limiting black men's access to ladies' cars. When it came to black men's access, railroad conductors were joined by white male passengers themselves in regulating admission to ladies' cars. If the conductor failed to prevent black men from riding first class, white male passengers sometimes took things into their own hands.

In 1882, Abe Murphy, a black schoolteacher from just across the Georgia border, provoked such a response when he boarded a train to Chattanooga and took a seat in the ladies' car, which at the time was occupied solely by white men. The conductor advised him that the railroad barred all blacks from riding in that car, but Murphy refused to give up his seat. Charles Carney, a vendor who sold newspapers and fruit on the train, wanted to eject Murphy but the other white men in the car refused to assist him, claiming that Murphy was entitled to his seat in the car. All this changed when a pair of white couples subsequently boarded the train. The two white men, with the aid and encouragement of Carney, seized Murphy and dragged him to the

evidence on this point is conflicting. For instance, compare Robinson v. Memphis \& C. R.R. 1879, 9, with Brown v. Memphis \& C. R.R., 1881, 58-59. 
smoker. Murphy suffered injuries that incapacitated him for days. (Murphy v. Western \& A. R.R. $1882 \& 1885)$

W.A. Brinkley, a Memphis minister, also seems to have provoked a violent confrontation, this time with a white passenger and a railroad brakeman, when he boarded a ladies' car on a Brownsville, Tennessee-to-Memphis run in 1885. Brinkley alleged that the passenger forced him out of the car at gunpoint. The passenger testified that he "took a hold" of Brinkley as the minister tried to enter the ladies' car, got into a "scuffle" with him, tore his clothes and forced him out of the car. In response to his ejection, Brinkley brought a state court suit in 1885 and a federal action thirteen years later, both unsuccessful. According to Brinkley, in his state suit the defendant's attorney warned the jury "against the danger to which they would subject their wives and daughters" if they decided in his favor. ${ }^{32}$ (Brinkley v. Louisville \& N. R.R. $1898 \& 1899)$

William Hooper Councill, a minister and principal of a black normal and industrial school, was met with an even more violent response in 1887 when he boarded a southbound ladies' car in Chattanooga. Councill boarded sometime between 9:00 PM and midnight and refused one or two requests by railroad officials that he vacate the coach. Several white men then took the initiative, grabbing him and beating him in the head with a lantern before removing him to another car. Several factors motivated the whites to beat and eject him: (1) the objections of

32 After the 1892 triple lynching that galvanized Ida B. Wells, Brinkley grew so discouraged by the state of race relations in Memphis that he moved his entire congregation to California. He was admitted to the bar in California, subsequently returned to Tennessee, and then brought his federal suit. (Tucker 1975, 47; Brinkley v. Louisville \& N. R.R. 1899) 
white women riding in the car to his presence; (2) his "insolence" in refusing both their and the railroad officials' requests to leave the car; and (3) Councill's casual seating posture, in which he threw one of his legs over the seat in front of him. The white passengers also testified that Councill was "exceedingly well dressed for a darkey" and that he was wearing "a high silk hat.",33 (Councill v. Western \& A. R.R. 1887a \& 1887b)

The presence of white women, real or potential, made riding first class particularly hazardous for black men like Councill, Brinkley and Murphy. ${ }^{34}$ Councill made matters worse by boarding at night, assuming a relaxed posture, and being unexpectedly well dressed and forceful in his refusal to move. Even when seemingly respectable, black men ran up against an impediment that black women faced in only attenuated form -- the need to stave off social equality.

"Social equality" was an ill-defined term in the New South, but it drew upon contemporary discourses that distinguished among political, civil and social equality between blacks and whites. In the 1880 s, the first two were accepted by many as the result of the Constitutional revolution effected by Reconstruction, but social equality was not. ${ }^{35}$ In the rhetoric

33 Councill, however, denied that he was wearing a silk hat. For more on Councill's life and career, see Brown 1963.

34 The record in Brinkley's case does not indicate whether or not white women were actually in the ladies' car when he was ejected.

35 The always-fuzzy distinction between political, civil and social equality had structured the Congressional debates over Reconstruction-era legislation and Constitutional Amendments. The core political right was the right to vote, while the core civil right was the right to sue and testify. 
of white New Southerners, social equality between blacks and whites was to be avoided at all costs. In practice this meant that in all interracial contexts -- theaters and trains for instance -blacks had to be subservient or separate. The Southern rhetoric of social equality went beyond this and also demanded that white men of differing classes and interests unify behind a program of keeping blacks politically and economically subservient, because social equality would lead to miscegenation, rape of white women by black men, and, in some versions, the amalgamation of the black and white races. As the Memphis Avalanche editor argued: "[e]very kind of social intercourse is a step in the direction of breaking down the barriers of race -- in other words towards miscegenation.” (Painter 1988, 47-67; Letwin 1998, 82, 154-55; Gaines 1996, 59; Hall 1979, 145-49; Fredrickson 1971, 282; Cartwright 1976, 178)

In William Councill's case, a substantial part of the railroad's effort was devoted to proving that he advocated social equality. The railroad's attorneys tried to introduce evidence that Councill had raped one of his former students, and that he desired "social equality" because he had been associated with a local protest against railroad segregation. During the deposition of E.F. Grizzard, a black man who was the most forceful witness on Councill's behalf, the sexual tension was so great that Councill's attorneys noted, on the record, that Grizzard had risen and offered his seat to a white lady who had entered the room during the deposition. They felt the need to draw the line between Grizzard's forceful opposition to segregation and any irreverence

The core social right was the right to select one's associates. The boundaries between them would be worked out by social struggles that have continued to this day. (Tushnet 1987, 885-90) 
for white women. ${ }^{36}$ (Councill v. Western \& A. R.R. 1887a, Wise, Blakemore, Hall, Rand, Grizzard Depos.)

Even the racial language in black men's cases manifested a degree of animosity not present in black women's cases. Charles Whitsitt, William Councill's assailant, casually referred to him as a "darkey" several times in his testimony. Federal judge David Key, presiding in Murphy's case and an otherwise insightful critic of the rhetoric of social equality, also used this term several times to refer to blacks in a folksy address to the all-white jury sitting in that case. The word "nigger" also appears in Judge Key's summation of the trial testimony, although Key appears to have used it as part of a verbatim summary of Carney's testimony rather than of his own accord. ${ }^{37}$ (Councill v. Western \& A. R.R. 1887a; Murphy v. Western \& A. R.R. 1882)

Ladies' cars stood at a crossroads of race, class and gender currents in Southern society, and were an important arena in the debate over social equality. The rhetoric of social

36 The Interstate Commerce Commission, however, ruled that this evidence was inadmissible. (Councill v. Western \& A. R.R. 1887a)

37 Although the written trial record of Judge Key's jury charge contains this language, it appears to have been excised from the somewhat different version of his charge that was published in the federal reporter. (Murphy v. Western \& A. R.R. 1885) Whitsitt, testifying for the railroad in Councill's case, seems to have realized that "darkey" was a term of opprobrium. He originally testified that railroad officials used this term, but after prodding by the railroad's attorneys, changed his testimony and reported that they used the word "colored." Whitsitt, however, not being a defendant in the case, continued to use the term "darkey" in his own testimony. (Councill v. Western \& A. R.R. 1887a) 
equality was a call for white men to reassert a partially-imagined antebellum patriarchal role in the face of the political, economic and social changes overtaking the New South. The discourse of social equality also represented an effort to maintain the privileges of whiteness when white skin could no longer confidently be associated with superior social position. Ladies' cars inscribed railroad travel with the language of patriarchy and class privilege, and the presence of black men in these cars raised explosive questions. Could black men also claim the privileges of respectable white patriarchs? Would those privileges extend beyond the boundaries that separated white from black households, giving black men authority over, and possibly sexual access to, white women? The rape accusation against Councill signaled the emergence of the familiar "black beast rapist" image of black men. Black men's exclusion from ladies' cars could be justified if black men were not patriarchs, but instead the opposite -- lustful, predatory creatures who could not control their desire for white women.

The discourse of social equality did have its white detractors. Judge Key, for instance, rejected the more extreme dictates of social equality's rhetoric, asserting in his 1885 Tennessee Bar Association speech that he would "prefer to sit by a genteel well bred negro than by a dirty, filthy disgusting white man.” In Murphy's case, Key expressed particular concern that blacks of "genteel appearance, good repute, and good behavior" were being relegated to smoking cars. For Key, the proper division of social space was not by race, but by class -- respectable blacks could have some social contact with respectable whites, so long as both groups 
disassociated themselves from the lower classes. ${ }^{38}$ (Key 1885, 292; Murphy v. Western \& A. R.R. $1885,640)$

The depth of white paternalistic sentiment in the mid-1880s was such that Key's sentiments could be echoed by fellow Democrats. In the mid-1880s, certain factions within the state Democratic party courted black voters, and prominent Democratic newspaper editors began expressing concern over the relegation of middle class blacks to the smoking cars, where they were forced to ride with the disreputable elements of both races. Some Democrats called for enforcement of the 1881 law to provide first class, albeit segregated, passage to respectable blacks, while others argued that blacks could ride first class if they presented themselves properly. The debate, however, continually strayed into the incendiary territory of social equality, as when one editor asserted that if paternalistic sentiments prevailed within the Democratic party, white men "who don't want their wives and daughters to mix up in the same car, board at the same hotel and tend the same theater with the negro, will desert that party." Social equality arguments soon made the paternalistic position untenable, and by the end of the decade editors in both Democratic factions had moved to racial segregationist positions. (Cartwright 1976, 43-47, 16871)

If whites could not debate the question of racial segregation without worrying about social equality, black Tennesseans did the opposite. Black critics of segregation asserted that the only issue was legal, or civil, equality between blacks and whites, and that enforcement of

38 Key was already notable as the maverick Southern Democrat who had served in President Hayes' cabinet. For a fuller, although romantic, account of Key's political life, see Abshire 1967. 
blacks' civil rights would leave the social distinctions between blacks and whites intact. ${ }^{39}$ Nonetheless, Tennessee's African-Americans recognized the link between riding first class and respectable manhood and womanhood, as when a group of Nashville black businessmen explained their desire for equal access to public conveyances by arguing that "we want to be treated as men." Respectable black Tennesseans acknowledged and approved of the class and gender distinctions that ladies' cars symbolized. They simply wanted to be included in the better classes. By the late 1880s, however, they found their endorsement of class and gender privilege turned back on them, as whites began to justify segregation based on the idea that respectable whites needed to be protected from dissolute blacks. One well-known white newspaper editor, for instance, initially argued for class distinctions on common carriers in order to protect blacks from the vulgar conduct of lower class whites, but soon turned to justifying racial segregation based on "[t]he disagreeable conduct and filth of the great majority" of African-Americans. (Lamon 1977, 20; Rabinowitz 1978, 194; Cartwright 1976, 168-71, 186-93)

Even white paternalism's most particulate defender, Judge Key, seems to have realized that his aristocratic vision was a losing one in the 1880s. Describing a recent train trip in

39 Paternalistic white judges like David Key and John Marshall Harlan sometimes echoed this rhetorical move, arguing that blacks and whites could mix in public spaces without altering their social positions, or calling into question the superiority of the white race. (Plessy v. Ferguson 1896, 558-62; Civil Rights Cases 1883, 59-61; Key 1885, 292) Judges who were more comfortable with segregationist laws and practices made the opposite argument -- that challenges to segregation were attempts to force social, rather than civil equality between blacks and whites. (Plessy v. Ferguson 1896, 551-52; Civil Rights Cases 1883, 24-25; Riegel 1984, 33-35) 
his charge to the jury in Murphy's case, he noted that a "gentleman" had entered the ladies' car drinking whisky and been tolerated, but that if he had been poor or black he would have been ejected. (Murphy v. Western \& A. R.R. 1882) Whatever class divisions that ladies' cars still inscribed, as the 1880s wore on those divisions began to have difficulty crossing racial boundaries. Symbolic of the changed climate, and of the increased power of the rhetoric of social equality, were the legal positions taken by the railroads themselves. In 1879 and 1880, for instance, the Memphis and Charleston Railroad's litigating position was that it made no racial distinctions in its cars. By the mid-1880s, however, the M \& C freely admitted that it tried to confine most of its black passengers to the smoking car. Another sign of changing attitudes was the introduction of a separate car for black passengers on the Cleveland, Tennessee-to-Nashville railroad line in 1888. (Cartwright 1976, 169-71, 187; Robinson v. Memphis \& C. R.R. 1879, 9; Brown v. Memphis \& C. R.R. 1880a; Logwood v. Memphis \& C. R.R. 1885)

\section{The Coming of De Jure Railroad Segregation in Tennessee}

White Tennesseans' segregationist impulses were augmented by the erosion of the state's two-party system. The rhetoric of social equality had often been a political argument, mobilized by white Democrats as a bid for the loyalty of white male voters, but in Tennessee that loyalty had been suspect. The Republican party remained potent in the state, drawing its strength from both the black belt and poor white counties and sending a number of black Republicans to the state legislature. By the late 1880s, however, arguments for black degeneracy began to be extended from public accommodations to other areas of public life. For instance, whites of various political persuasions started to unify in their criticism of black voters as irresponsible in their exercise of the franchise, arguing that only those of "intelligence and property" (now 
assumed to be white men) should govern. ${ }^{40}$ Even the endorsement by some blacks of prohibition came back to haunt them, as prohibitionists blamed black voters for the failure of a statewide prohibition referendum. Beginning in 1886 , Democrats began to carry previously Republican districts, often through the use of both intimidation and fraud. In January 1889, the convening of a state legislature in which Democrats held two-thirds majorities in both houses paved the way for the enactment, during the next two calendar years, of secret ballot, voter registration, and poll tax laws that largely eliminated blacks as a counterweight to Democratic strength. (Cartwright 1976, 199-253; Hart 1975, 266-73; Kousser 1974, 104-23; Rabinowitz 1978, 325-27)

In this political climate the state legislature enacted a full-fledged railroad segregation law. Reflecting the increased political strength of the Democratic party and the appeal of white unity, the 1891 statute abolished all the ambiguities that had been present in the 1880s railroad legislation. Unlike the 1880s legislation, the new statute was drafted in clear terms

40 Arguments that African-Americans lacked the capacity for responsible exercise of the franchise were of long vintage. When, in the early nineteenth century, suffrage began to be based on capacity rather than property ownership, capacity arguments were mobilized to exclude blacks as well as women from the franchise. In the antebellum period, Tennessee had disfranchised those blacks who were eligible to vote in its 1834 constitution. Both proponents and opponents of the Fifteenth Amendment relied on capacity arguments, as did opponents of black suffrage at Tennessee's 1870 state constitutional convention. (Cogan 1997; Cartwright 1976, 4, 15-16) After losing in the Fifteenth Amendment and 1870 Tennessee constitutional debates, capacitybased arguments for restricting black suffrage acquired greater force in the racial climate of the late 1880 s and 1890 s. 
that required almost complete separation of passengers by race, and the new statute contained no language asserting that it protected the rights of black passengers. ${ }^{41}$ The new law explicitly empowered conductors to eject passengers seated in the other race's coach, and prohibited such passengers from challenging the conductor's decision in any Tennessee court. ${ }^{42}$ After several unsuccessful attempts, in 1905 the state legislature supplemented this law with a statute requiring racial segregation on streetcars. $^{43}$ (1891 Tenn. Acts, Ch. 52; 1905 Tenn. Acts, Ch. 150; Lamon 1977; Meier \& Rudwick, 1969)

These changes in Tennessee's racial climate were indicative of attitudes across the region. Fear of the "cruder classes" fueled disfranchising sentiments throughout the South, as the Republican party, as well as independents, continued to challenge the Democrats even in states without as robust a two-party system as Tennessee's. Tennessee newspapers began to carry suggestions that other states follow their lead in restricting the franchise, and whites in other Southern states took notice. In 1890 Mississippi followed in Tennessee's footsteps, adding additional disfranchising provisions to Tennessee's registration and poll tax requirements. Over

41 For most purposes, the 1891 law required complete segregation. As noted earlier, the statutory language did contain an exception for nurses.

42 As discussed earlier, under the old statutory regime, black passengers could and did sue under the common law to challenge conductors' decisions. They could even bring actions under the provisions of the statutory regime itself. (1881 Tenn. Acts, Ch. 155, § 2; 1882 Tenn. Acts, 3d Extraordinary Sess., Ch. 6, § 2)

43 In the late nineteenth century, streetcars had been among the least segregated social spaces in Tennessee. (Rabinowitz 1978, 192-94; Rabinowitz 1976, 343-45) 
the next two decades, every former Confederate state would institute a poll tax requirement, and many supplemented these with more circuitous disfranchising measures. Similar sentiments began to come to the fore on the subject of railroad segregation, as relatively lenient early railroad segregation laws such as those of Tennessee, Texas and Florida were succeeded by harsher enactments. In 1891 Texas joined Tennessee in strengthening its 1880s-era railroad segregation law, and three additional states enacted railroad segregation laws that year. Between 1888 and 1892, three other Southern state passed railroad segregation laws, followed by five more states between 1898 and 1907. (Hart 1975, 272-73; Rabinowitz 1978, 327; Kousser 1973, 682-83; Ayers 1992, 148-49, 309; 1891 Texas Gen. Laws, Chs. 41, 103; Lofgren 1987, 22)

The new statutory enactments alone, however, did not change railroads' practices. Each enactment would be accompanied by continued social struggles and further hardening of white attitudes before racial segregation would be standard practice. Two years after the enactment of Tennessee's 1891 law, for instance, a black North Carolina man riding through the South reported that Tennessee railroads were inconsistent in their attempts to enforce racial segregation. By the late 1890s, however, the Louisville and Nashville Railroad had signs posted on its St. Louis-to-Nashville run designating black and white compartments, and by the first decade of the twentieth century its conductors were forcing black passengers on its Cincinnati-toNashville line to ride in a colored compartment for the Tennessee and Kentucky portions of the trip. The Memphis Street Railway Company refused to comply with the state legislature's initial foray into the area of streetcar segregation, but the company would later begin dividing up its cars up into black and white sections as required by the 1905 streetcar segregation law. (Gilmore 1996, 28; State v. Smith 1896; Mayfield v. Louisville \& N. R.R. 1906; Memphis St. Ry. v. State 1903a \& 1903b; Morrison v. State 1905 \& 1906) 
These changes in the law and in the railroads' practices also affected social relations. For instance, railroad travel no longer gave middle class black women an obvious claim to the mantle of white womanhood, since African-Americans were now grouped together regardless of gender or class. De jure segregation, however, did not eliminate all similarities between notions of black and white womanhood. Some railroads now banned smoking in black cars to prevent the dignity of black women from being offended, just as they banned the practice in white first class cars. (Mayfield v. Louisville \& N. R.R. 1906; Edwards v. Nashville, C. \& St. L. Ry. 1907) The shift to de jure segregation also signaled changes in the rhetoric of social equality. Prior conceptions of social equality had focused on contact between black men and white women in the ladies' car, but had paid little attention to the indiscriminate mixing of passengers in the smoking/second class cars. By the early 1890s, however, a new idea of race relations had emerged that mandated complete separation between blacks and whites regardless of gender or class.

Tennessee's African-Americans fashioned their own responses to the onset of de jure segregation. The 1905 streetcar segregation law provoked perhaps the most vigorous response of black Tennesseans to any legal enactment of the postbellum era, as they recognized the stakes behind the creation of the new segregationist regime. The Nashville Clarion, a local black newspaper, justified resistance to the 1905 streetcar law based on African-Americans' "manhood and culture, sobriety and self-respect" as well as "womanhood." The editor understood that the new approach to segregation challenged black aspirations to middle class identity. Tennessee's African-American communities organized streetcar boycotts in most of the state's major cities, and Memphis' black community raised $\$ 5,000$ for the appeal of a case challenging the constitutionality of the streetcar law. Spurred on by chapters of Booker T. 
Washington's National Negro Business League (NNBL), Nashville and Chattanooga blacks formed short-lived alternative transportation companies. The Nashville company was by far the most successful, raising thousands of dollars in investments by issuing stock and eventually purchasing a fleet of autobuses to transport black Nashvilleans. (Meier \& Rudwick 1969, 760; Meier \& Rudwick 1969, 755-63; Lamon 1977, 20-36)

As early as 1890, black Tennesseans had begun calling for self-help and the formation of black businesses as a response to segregation, and the new statutes reinforced these tendencies. In 1903 the annual meeting of the NNBL was held in Nashville, and NNBL-affiliated black businessmen provided support for Nashville's boycott, its black transit company, and a new black newspaper, the Nashville Globe, founded to promote boycott efforts. The Globe staked out an independent position among the black press, eschewing any endorsement of white paternalism and emphasizing black self-sufficiency and black racial purity instead. While endorsing black opposition to racial discrimination, the paper also promoted black business development and pride in separate black institutions. While the boycott and transportation company efforts would prove to be short-lived, the Globe would continue to promote its own brand of black independence for decades. (Cartwright 1976, 195; Lamon 1977, 1-36)

Black Tennesseans' varied responses to the new segregation laws signaled the strengthening of alternate bases for middle class African-American identity. The ambiguous railroad segregation of the 1870 s and 1880 s had left room for an idea of middle class black identity based, in part, on white middle class respectability, and had even induced white paternalists to adopt class-based ideas of social organization. The coming of de jure segregation, however, muted these impulses and strengthened competing ideas. While African-Americans continued to push for access to white cars, black ownership and black patronage of separate 
transportation companies now emerged as alternate sources of respectability. Another alternative was exemplified by a series of cases brought by black women in neighboring Kentucky, who instead of bringing suit to gain access to white railroad cars, sued to keep drunken or insulting white men from riding in black railroad cars. (Conley v. Central Ky. Traction Co. 1913; Bailey v. Louisville \& N. R.R. 1898; Wood v. Louisville \& N. R.R. 1897; Quinn v. Louisville \& N. R.R. 1895) Such responses to the emergence of de jure segregation ensured that the world of Jim Crow would be more complicated than its creators had intended. While the emergence of de jure segregation placed limits on black middle class aspirations, at the same time it forced AfricanAmericans to construct new narratives of respectability and freedom. 


\section{CONCLUSION}

The debate over C. Vann Woodward's The Strange Career of Jim Crow mobilized arguments for sociolegal change that remain powerful in the writing of American legal history: (1) Woodward's idea of law as a potent agent for social change, or at the very least as a marker of contemporaneous social changes, and (2) Woodward's critics' notion of a less active role for law, with legal changes lagging behind, and passively reflecting, social changes taking place elsewhere in American society. The advent of de jure and de facto railroad segregation in late nineteenthcentury Tennessee challenges both these conventional ways of imagining sociolegal change. The coming of racial segregation on Tennessee railroads was a thirty-year process involving compromises, contradictions, retreats, and false starts. The language that the participants used in these sociolegal conflicts constantly slipped from their grasp, as arguments about class, gender and race segregation blended into one another. Laws, social relations, party politics and identity were all interdependent areas of conflict that both helped and impeded Tennesseans in their struggle to define place and identity in the New South.

Railroad cars confronted postbellum Tennesseans with unfamiliar social terrain and new social challenges. Their first response, drawing on common nineteenth-century conventions, was to construct railroad travel as a patriarchal experience, with gender and class separation reinforced by the sanction of the judicial decisions. That solution, however, was overtaken by the revolution in Southern polities brought about by emancipation, black citizenship, the post-Civil War constitutional amendments and civil rights laws, and the assertiveness of middle class blacks in claiming access to social spaces occupied by respectable whites. Where did black men and women, particularly the middle class, fit within a system whose only ostensible categories were those of gender and class? The seemingly obvious solution from a twentieth-century perspective - 
- complete racial separation -- did not seem obvious at all at the time. Respectable white patriarchs sometimes found more in common with black middle class riders than with lower class whites. The modern terms of the Woodward debate have often obscured the fact that even those blacks who rode second class traveled in the same coaches as poor whites. Gender, a category largely absent from the Woodward debate, was often the most explosive element in this mix, as both black men and black women raised the question of whether the norms of patriarchy crossed racial lines.

The law intersected with identity and social structures to inhibit as well as aid the participants in this process. Throughout the 1870s and 1880s, black and white Tennesseans made strategic use of the law, invoking state common and statutory law as well as federal civil rights law to bolster their claims on social space. The law, however, could also exert a disciplining function, cabining claims and narrowing identities. Black Tennesseans often found themselves constrained by the separate-but-equal categories of common carrier law. Most black plaintiffs' true complaint was not that the ladies' and smoking cars provided unequal comforts, since, for the most part, they endorsed such class and gender-based distinctions. Rather, they thought that their respectable status entitled them to admission to the ladies' car regardless of the condition of the smoker. However, they kept falling back on the claim that the two cars were unequal -- their only available claim since courts consistently ruled that separating out black passengers was permissible so long as the blacks were given the same quality of accommodations as those given to the whites riding first class. When the Republican party finally collapsed and the fragile equilibrium of the 1870 s and 1880 s began to unravel, black plaintiffs' unwitting endorsement of separate-but-equal appeared to justify and even invite the move to strictly racial, but putatively equal, segregation. Tennessee's "solution" to the problem of black participation in public life 
would be mirrored by legislative enactments across the South, as one state after another enacted disfranchising and railroad segregation measures. In 1896, the United States Supreme Court would reinforce the emerging segregationist order with its decision in Plessy v. Ferguson.

The world of de jure segregation, however, would never be the stable regime of white-over-black that its architects envisioned. From its beginnings, cracks appeared in the segregationist regime as the law, as always, failed to control social practices and identity formation. Tennessee's African-Americans responded to the turn-of-the-century segregation laws with at least two different strategies for middle class identity creation -- one emphasizing black ownership of separate facilities and the other continuing to imagine the law as prohibiting segregation. In everyday life and in organized groups, blacks in Tennessee and across the South continued to both work within and oppose the world of Jim Crow. In 1920 for instance, Charlotte Hawkins Brown, a prominent black educator, used her ejection from a Memphis-bound railroad car to galvanize a biracial meeting of Southern women into interracial cooperation. The validity of the interracialist approach seemed to be borne out in the succeeding decades when NAACP-affiliated attorneys began to mount new challenges to segregation in Tennessee, and when the NAACP subsequently had the separate-but-equal principle struck down in Brown $v$. Board of Education. White Southerners also continued their struggle with the law, using Brown as a rallying point for a backlash against desegregation that, ironically, produced its own counterbacklash of further civil rights initiatives. (Hall 1979, 90-95; Gilmore 1996, 200-01; State ex rel. Michael v. Witham 1942; Klarman 1994)

Perhaps the most eloquent statement of the constitutive power of law in forming identity, and of the close relationship between legal and social change, was that made by Martin Luther King, Jr. in his 1963 "Letter from Birmingham Jail." King, jailed under the force of a state 
court injunction that had been issued to defend racial segregation in Birmingham, was forced to respond to those who said he had gone too far in defying the law. King justified his defiance in both moral and practical terms. Segregationist laws were immoral, but also important was the fact that the practice of racial segregation, and its justification in law, marked black identity as inferior and white as superior. For King it was not enough to wait for the laws to change, because legal change only came about through concerted social effort and moral betterment. Likewise, social and moral movements needed legal sanction. Those, like him, who defied the law had to generously accept the penalty of imprisonment. (King 1964, 82-87) This mutual dependence of legal change and social change, of legal authority, social authority and identity, was something that black and white Southerners had been struggling with for at least ninety years, since they began their first, halting steps toward the system of racial segregation that King sought to eradicate. 


\section{REFERENCES}

Abshire, David M. 1967. The South Rejects a Prophet: The Life of Senator D.M. Key, 18241900. New York: Frederick A. Praeger.

Ayers, Edward L. 1992. The Promise of the New South: Life After Reconstruction. New York: Oxford University Press.

Bardaglio, Peter W. 1995. Reconstructing the Household: Families, Sex, and the Law in the Nineteenth-Century South. Chapel Hill: University of North Carolina Press.

Bates, Beth Tompkins. 1997. A New Crowd Challenges the Agenda of the Old Guard in the NAACP, 1933-41. American Historical Review 102: 340-77.

Blassingame, John W. 1973. Black New Orleans, 1860-1880. Chicago: University of Chicago Press.

Brown, Charles A. 1963. William Hooper Councill: Alabama Legislator, Editor and Lawyer. Negro History Bulletin. 26: 171-73.

Brown, Elsa Barkley. 1994. Negotiating and Transforming the Public Sphere: African-American Political Life in the Transition from Slavery to Freedom. Public Culture. 7: 107-46. 
Cartwright, Joseph H. 1976. The Triumph of Jim Crow: Tennessee Race Relations in the 1880s. Knoxville: University of Tennessee Press.

Cell, John W. 1982. The Highest Stage of White Supremacy: The Origins of Segregation in South Africa and the American South. New York: Cambridge University Press.

Clark, Elizabeth B. 1990. Matrimonial Bonds: Slavery and Divorce in Nineteenth-Century America. Law and History Review 8: 25-54.

Cogan, Jacob Katz. 1997. The Look Within: Property, Capacity, and Suffrage in NineteenthCentury America. Yale Law Journal. 107:473-98.

Collins, Patricia Hill. 1991. Mammies, Matriarchs, and Other Controlling Images. In Patricia Hill Collins. Black Feminist Thought: Knowledge, Consciousness, and the Politics of Empowerment. New York: Routledge.

Crenshaw, Kimberlé, Neil Gotanda, Gary Peller and Kendall Thomas, eds. 1995. Critical Race Theory: The Key Writings that Formed the Movement. New York: New Press.

DeCosta-Willis, Miriam. 1991. Ida B. Wells's Diary: A Narrative of the Black Community of Memphis in the 1880s. West Tennessee Historical Society Papers 45: 35.

-----, ed. 1995. The Memphis Diary of Ida B. Wells. Boston: Beacon Press. 
Dale, Elizabeth. 1997. "Social Equality Does Not Exist among Themselves, nor among Us":

Baylies vs. Curry and Civil Rights in Chicago, 1888. American Historical Review 102: 311-39.

Davis, Peggy Cooper. 1994. Contested Images of Family Values: The Role of the State. Harvard Law Review 107: 1348-73.

Delgado, Richard, ed. 1995. Critical Race Theory: The Cutting Edge. Philadelphia: Temple University Press.

Duster, Alfreda M., ed. 1970. Crusade for Justice: The Autobiography of Ida B. Wells. Chicago: University of Chicago Press.

Edwards, Laura F. 1997. Gendered Strife and Confusion: The Political Culture of Reconstruction. Urbana: University of Illinois Press.

Folmsbee, Stanley J. 1949. The Origin of the First "Jim Crow" Law. Journal of Southern History 15: 235. Reprinted in Donald G. Nieman, ed. African-American Life in the PostEmancipation South, 1861-1900. Vol. 11: African-Americans and the Emergence of Segregation, 1865-1900. New York: Garland Publishing. 1994.

Forbath, William, Hendrik Hartog, and Martha Minow. 1985. Introduction: Legal Histories From Below. Wisconsin Law Review 1985: 759-66. 
Forbath, William E.. 1991. Law and the Shaping of the American Labor Movement.

Cambridge: Harvard University Press.

Franklin, John Hope. 1974. The Enforcement of the Civil Rights Act of 1875. Prologue 6: 22535.

Fredrickson, George M. 1971. The Black Image in the White Mind: The Debate on AfroAmerican Character and Destiny, 1817-1914. New York: Harper \& Row.

Gaines, Kevin K. 1996. Uplifting the Race: Black Leadership, Politics, and Culture in the Twentieth Century. Chapel Hill: University of North Carolina Press.

-----. 1997. Rethinking Race and Class in African-American Struggles for Equality, 1885-1941. American Historical Review 102: 378-87.

Gilmore, Glenda Elizabeth. 1996. Gender and Jim Crow: Women and the Politics of White Supremacy in North Carolina, 1896-1920. Chapel Hill: University of North Carolina Press.

Gordon, Sarah Barringer. 1996. "The Liberty of Self-Degradation”: Polygamy, Woman Suffrage, and Consent in Nineteenth-Century America. Journal of American History. 83: 81547. 
Greenwood, Janette Thomas. 1994. Bittersweet Legacy: The Black and White "Better Classes" in Charlotte, 1850-1910. Chapel Hill: University of North Carolina Press.

Hall, Jacquelyn Dowd. 1979. Revolt Against Chivalry: Jessie Daniel Ames and the Women's Campaign Against Lynching. New York: Columbia University Press.

-----. 1983. “The Mind that Burns in Each Body": Women, Rape, and Racial Violence. In Ann Snitow, Christine Stansell, and Sharon Thompson, eds. Powers of Desire: The Politics of Sexuality. New York: Monthly Review Press.

Harris, Cheryl I. 1993. Whiteness as Property. Harvard Law Review 106: 1707-91.

Hart, Roger L. 1975. Redeemers Bourbons and Populists: Tennessee 1870-1896. Baton Rouge: Louisiana State University Press.

Hartog, Hendrik. 1987. The Constitution of Aspiration and "The Rights that Belong to Us All." Journal of American History 74: 1013-34.

-----. 1997. Lawyering, Husbands' Rights, and "the Unwritten Law" in Nineteenth-Century America. Journal of American History 84: 67.

Higginbotham, Evelyn Brooks. 1992. African-American Women's History and the Metalanguage of Race. Signs 17: 251-74. 
-----. 1993. Righteous Discontent: The Women's Movement in the Black Baptist Church, 18801920. Cambridge: Harvard University Press.

Hodes, Martha. 1997. White Women, Black Men: Illicit Sex in the Nineteenth-Century South. New Haven: Yale University Press.

hooks, bell. 1981. Ain't I a Woman: Black Women and Feminism. Boston: South End Press.

Hunter, Tera W. 1997. To 'Joy My Freedom: Southern Black Women's Lives and Labors After the Civil War. Cambridge: Harvard University Press.

Iola [Ida B. Wells]. 1885. Woman's Mission. New York Freeman, 26 December. Reprinted in DeCosta-Willis 1995.

Iola [Ida B. Wells]. 1886. A Story of 1900. Fisk Herald, April 1886. Reprinted in DeCostaWillis 1995.

Iola [Ida B. Wells]. 1887. Our Women. New York Freeman, 1 January. Reprinted in DeCostaWillis 1995.

Iola [Ida B. Wells]. 1888. The Model Woman: A Pen Picture of the Typical Southern Girl. New York Freeman, 18 February. Reprinted in DeCosta-Willis 1995. 
Johnson, Franklin. 1979. The Development of State Legislation Concerning the Free Negro. Westport, Conn.: Greenwood Press.

Kelley, Robin D.G. 1994. Race Rebels: Culture, Politics, and the Black Working Class. New York: The Free Press, Macmillan.

Key, David M. 1885. The Legal and Political Status of the Negro. Reprinted in Journal of Negro History 54 (1969): 288.

King, Martin Luther, Jr. 1964. Letter From Birmingham Jail. In Martin Luther King, Jr. Why We Can't Wait. New York: Harper \& Row.

Klarman, Michael J. 1994. How Brown Changed Race Relations: The Backlash Thesis. Journal of American History 81: 81-118.

Knupfer, Anne Meis. 1995. “Toward a Tenderer Humanity and a Nobler Womanhood”: AfricanAmerican Women's Clubs in Chicago, 1890 to 1920. Journal of Women's History 7, no. 3: 5876.

Kousser, J. Morgan. 1973. Post-Reconstruction Suffrage Restrictions in Tennessee: A New Look at the V.O. Key Thesis. Political Science Quarterly. 88:655-83. Reprinted in Donald G. Nieman, ed. African-American Life in the Post-Emancipation South, 1861-1900. Vol. 6: 
African-Americans and Southern Politics from Redemption to Disfranchisement. New York: Garland Publishing. 1994.

Kousser, J. Morgan. 1974. The Shaping of Southern Politics: Suffrage Restriction and the Establishment of the One-Party South, 1880-1910. New Haven: Yale University Press.

Lamon, Lester C. 1977. Black Tennesseans 1900-1930. Knoxville: University of Tennessee Press.

Letwin, Daniel. 1998. The Challenge of Interracial Unionism: Alabama Coal Miners, 18781921. Chapel Hill: University of North Carolina Press.

Litwack, Leon F. 1961. North of Slavery: The Negro in the Free States, 1790-1860. Chicago: University of Chicago Press.

Lofgren, Charles A. 1987. The Plessy Case: A Legal-Historical Interpretation. New York: Oxford University Press.

López, Ian F. Haney. 1996. White By Law: The Legal Construction of Race. New York: New York University Press.

Maclean, Nancy. 1994. Behind the Mask of Chivalry: The Making of the Second Ku Klux Klan. New York: Oxford University Press. 
McCluskey, Audrey Thomas. 1997. "We Specialize in the Wholly Impossible": Black Women School Founders and Their Mission. Signs 22: 403-26.

Meier, August and Elliott Rudwick. 1969. Negro Boycotts of Jim Crow Streetcars in Tennessee. American Quarterly 21: 755-63.

Minter, Patricia Hagler. 1995. The Failure of Freedom: Class, Gender, and the Evolution of Segregated Transit Law in the Nineteenth-Century South. Chicago-Kent Law Review. 70: 9931009.

Painter, Nell Irvin. 1988. "Social Equality,” Miscegenation, Labor, and Power. In Numan V. Bartley, ed. The Evolution of Southern Culture. Athens: University of Georgia Press.

Proceedings of the Fourth Annual Meeting of the Bar Association of Tennessee. 1885. Nashville: Marshall \& Bruce.

Rabinowitz, Howard N. 1976. From Exclusion to Segregation: Southern Race Relations, 18651890. Journal of American History 63: 325-50.

-----. 1978. Race Relations in the Urban South, 1865-1890. New York: Oxford University Press. 
-----. 1988. More Than the Woodward Thesis: Assessing The Strange Career of Jim Crow. Journal of American History 75: 842.

Riegel, Stephen J. 1984. The Persistent Career of Jim Crow: Lower Federal Courts and the “Separate but Equal” Doctrine, 1865-1896. American Journal of Legal History 28: 17.

Schechter, Patricia Ann. 1993. "To Tell the Truth Freely": Ida B. Wells and the Politics of Race, Gender, and Reform in America, 1880-1913. Ph.D. diss., Princeton University.

-----. 1998. “All the Intensity of My Nature”: Ida B. Wells, Anger, and Politics. Radical History Review 70: 48-77.

Somerville, Diane Miller. 1995. The Rape Myth in the Old South Reconsidered. Journal of Southern History. 61: 481-518.

Stover, John F. 1955. The Railroads of the South 1865-1900: A Study in Finance and Control. Chapel Hill: University of North Carolina Press.

Terrell, Mary Church. 1940. A Colored Woman in a White World. Washington, D.C.: Ransdell Inc.

Thomas, William Griffith III. 1995. Lawyering for the Railroad: A Study of Business and Law in the New South, 1880-1916. Ph.D. diss., University of Virginia. 
Thompson, E.P. 1975. Whigs and Hunters: The Origin of the Black Act. New York: Pantheon Books, Random House.

Tomlins, Christopher L. 1993. Law, Labor and Ideology in the Early American Republic. New York: Cambridge University Press.

Tucker, David M. 1975. Black Pastors and Leaders: Memphis, 1819-1972. Memphis, Tenn.: Memphis State University Press.

Tushnet, Mark. 1987. The Politics of Equality in Constitutional Law: The Equal Protection Clause, Dr. Du Bois, and Charles Hamilton Houston. Journal of American History. 74: 884903.

Wade, Richard C. 1964. Slavery in the Cities: The South, 1820-1860. New York: Oxford University Press.

Welke, Barbara Y. 1995. When All the Women Were White, and All the Blacks Were Men: Gender, Class, Race, and the Road to Plessy, 1855-1914. Law and History Review 13: 261-316.

White, Deborah Gray. 1985. Ar'n't I a Woman? Female Slaves in the Plantation South. New York: W.W. Norton and Company. 
-----. 1993. The Cost of Club Work, the Price of Black Feminism. In Nancy A. Hewitt and Suzanne Lebsock, eds. Visible Women: New Essays on American Activism. Urbana: University of Illinois Press.

White, John H., Jr. 1978. The American Railroad Passenger Car. Baltimore: Johns Hopkins University Press.

Williams, Patricia J. 1991. The Alchemy of Race and Rights. Cambridge: Harvard University Press.

Williamson, Joel. 1965. After Slavery: The Negro in South Carolina During Reconstruction, 1861-1877. Chapel Hill: University of North Carolina Press.

------, ed. 1968. The Origins of Segregation. Boston: D.C. Heath and Company, Raytheon Education Company.

-----. 1984. The Crucible of Race: Black-White Relations in the American South Since Emancipation. New York: Oxford University Press.

Wing, Adrien Katherine, ed. 1997. Critical Race Feminism: A Reader. New York: New York University Press. 
Woodward, C. Vann. 1971a. Origins of the New South 1877-1913. Baton Rouge: Louisiana State University Press.

Woodward, C. Vann. 1971b. American Counterpoint: Slavery and Racism in the North-South Dialogue. Boston: Little, Brown and Company.

Woodward, C. Vann. 1974. The Strange Career of Jim Crow. 3d rev. ed. New York: Oxford University Press.

Woodward, C. Vann. 1986. Thinking Back: The Perils of Writing History. Baton Rouge: Louisiana State University Press.

Wynes, Charles E. 1961. Race Relations in Virginia, 1870-1902. Charlottesville: University of Virginia Press.

Yngvesson, Barbara. 1997. Negotiating Motherhood: Identity and Difference in "Open” Adoptions. Law and Society Review. 31: 31-80. 


\section{CASES}

Bailey v. Louisville \& N. R.R. 1898. 44 S.W. 105 (Ky.)

Brinkley v. Louisville \& N. R.R. 1898. Trial Record. U.S. Circuit Court, Memphis, Western District of Tennessee, B/50/12/36, Box 80. National Archives, Atlanta Regional Archives Branch, East Point, Georgia.

Brinkley v. Louisville \& N. R.R. 1899. 95 F. 345 (C.C.W.D. Tenn.).

Brown v. Memphis \& C. R.R. 1880a. 4 F. 37 (C.C.W.D. Tenn.).

Brown v. Memphis \& C. R.R. 1880b. 5 F. 499 (C.C.W.D. Tenn.).

Brown v. Memphis \& C. R.R. 1881. 7 F. 51 (C.C.W.D. Tenn.).

Charge to Grand Jury -- Civil Rights Act. 1875. 30 F. Cas. 1005 (C.C.W.D. Tenn.) (No. $18,260)$.

Chesapeake, O. \& Sw. R.R. v. Wells. 1885a. Trial Record. No. 312, Circuit Court of Shelby County, Microfilm Accession Number 1425. Tennessee State Library and Archives, Nashville, Tennessee. 
Chesapeake, O. \& Sw. R.R. v. Wells. 1885b. Trial Record. No. 319, Circuit Court of Shelby County, Microfilm Accession Number 1425. Tennessee State Library and Archives, Nashville, Tennessee.

Chesapeake, O. \& Sw. R.R. v. Wells. 1887. 4 S.W. 5 (Tenn.).

Civil Rights Cases. 1883. 109 U.S. 3.

Conley v. Central Ky. Traction Co. 1913. 154 S.W. 41 (Ky.)

Councill v. Western \& A. R.R. 1887a. Trial Record. RG134, Formal Dockets 1887-1924, Interstate Commerce Commission, Box 6, Docket No. 21. National Archives at College Park, College Park, Maryland.

Councill v. Western \& A. R.R. 1887b. 1 Interstate Com. Rep. 638, 1 I.C.C. 339.

Edwards v. Nashville, C. \& St. L. Ry. 1907. 12 I.C.C. 247.

Logwood v. Memphis \& C. R.R. 1883. Trial Record. Civil 2792, U.S. Circuit Court, Memphis, Western District of Tennessee, B/15/25. National Archives, Atlanta Regional Archives Branch, East Point, Georgia. 
Logwood v. Memphis \& C. R.R. 1885. 23 F. 318 (C.C.W.D. Tenn.).

Mayfield v. Louisville \& N. R.R. 1906. Trial Record. Middle Tennessee, Box 1755, Tennessee State Library and Archives, Nashville, Tennessee.

Memphis \& C. R.R. v. Benson. 1884. Trial Record. Circuit Court of Shelby County. Tennessee State Library and Archives, Nashville, Tennessee.

Memphis \& C. R.R. v. Benson. 1887. 4 S.W. 5 (Tenn.)

Memphis St. Ry. v. State. 1903a. Trial Record. West Tennessee, Box 854, Tennessee State Library and Archives, Nashville, Tennessee.

Memphis St. Ry. v. State. 1903b. 75 S.W. 730 (Tenn.).

Morrison v. State. 1905. Trial Record. West Tennessee No. 961, Tennessee State Library and Archives, Nashville, Tennessee.

Morrison v. State. 1906. 95 S.W. 494 (Tenn.).

Murphy v. Western \& A. R.R. 1882. Trial Record. United States Circuit Court, Chattanooga, Eastern District of Tennessee, Record Group 21, B/50/01/1, Box 2. National Archives, Atlanta Regional Archives Branch, East Point, Georgia. 
Murphy v. Western \& A. R.R. 1885. 23 F. 637 (C.C.E.D. Tenn., S.D.).

Quinn v. Louisville \& N. R.R. 1895. 32 S.W. 742 (Ky.).

Robinson v. Memphis \& C. R.R. 1879. Trial Record. United States Supreme Court, Records and Briefs, Civil Rights Cases, 109 U.S. 3 (1883).

State v. Smith. 1896. Trial Record. Middle Tennessee, Box 1258, Tennessee State Library and Archives, Nashville, Tennessee.

State ex rel. Michael v. Witham. 1942. 165 S.W.2d 378 (Tenn.).

Wood v. Louisville \& N. R.R. 1897. 42 S.W. 349 (Ку.) 


\section{STATUTES}

Civil Rights Act of 1875, 18 Stat. 335 (March 1, 1875).

1887 Florida Acts, Ch. 3743 (May 19, 1887).

Tennessee Act of March 12, 1868, No. 46, Ch. 66. In C.W. Folsom. ed. Certain Acts of the General Assembly and Extracts from the Code of 1857-58 of the State of Tennessee Relating Generally to Railroads. Nashville: The Republican Banner Office. 1869.

1875 Tenn. Acts, Ch. 130 (March 24, 1875).

1881 Tenn. Acts, Ch. 155 (April 7, 1881).

1882 Tenn. Acts, 3d Extraordinary Sess., Ch. 6 (May 22, 1882).

1891 Tenn. Acts, Ch. 52 (March 27, 1891).

1905 Tenn. Acts, Ch. 150 (April 4, 1905).

1889 Texas Gen. Laws, Ch. 108 (April 6, 1889).

1891 Texas Gen. Laws, Ch. 41 (March 19, 1891). 
1891 Texas Gen. Laws, Ch. 103 (April 11, 1891). 
ENDNOTES 